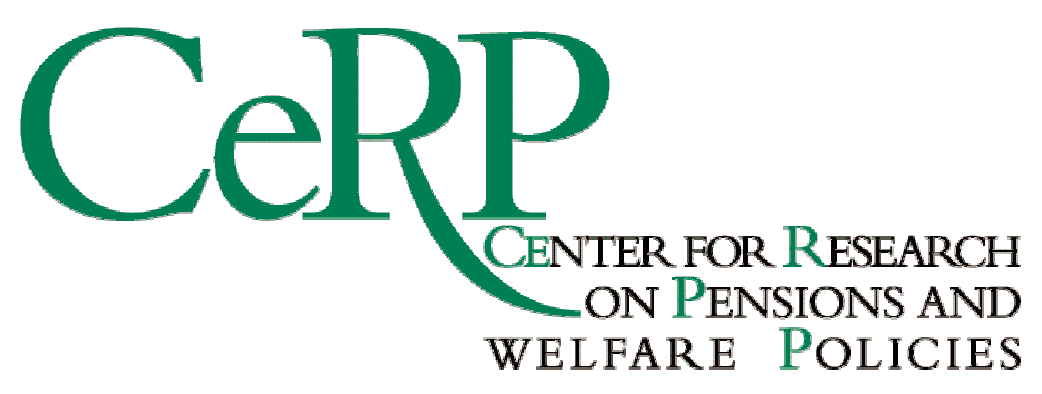

Working Paper 6/01

\title{
THE EFFECTS OF IMMIGRATION INFLOWS ON THE SUSTAINABILITY OF THE ITALIAN WELFARE STATE
}

\author{
Flavia Coda Moscarola
}

- CeRP (Center for Research on Pensions and Welfare Policies)

Via Real Collegio, 30

10024 Moncalieri (Turin)

Tel. +39.011.6402402

e.mail: coda@cerp.unito.it 


\begin{abstract}
$\underline{\text { Abstract }}$
This paper implements a set of generational accounts to estimate the impact of immigration on the sustainability of the Italian welfare state. Italians' net tax-age profiles are reconstructed on the basis of surveys; most of the immigrants' net tax-age profiles are reconstructed indirectly. According to our estimates immigration can only partly relieve the burden that current fiscal policy will put on future generations. In the baseline case immigrants' total net taxes reduce the intergenerational imbalance by only 6 percentage points. Interestingly, immigration appears to be more effective in this regard if the immigrants stay in Italy until they die. However, immigration alone cannot restore long-term solvency. Fundamental reform is needed.
\end{abstract}

I would like to thank Carlo Mazzaferro for his careful supervision. I am also grateful to Elsa Fornero and Alessandra Venturini for advice, to Pier Marco Ferraresi, Daniela Mantovani and Claudia Villosio for providing, respectively, the pension projections, the income tax age profile, and the immigrants' social security wage profile. I am indebted to Margherita Borella for her help in treating the Banca d'Italia survey, Fabio Platini, Giovanna Segre for their friendly support, and to the participants at CeRP lunch seminars for their comments.

Any errors are attributable to myself alone. 


\section{Introduction}

For a decade now Italy has been a country of net immigration. With a yearly inflow of 50,000 people, the total immigrant population reached 1 million in 1999. For Italy, traditionally a country of emigration, this is a historical watershed with profound socio-economic implications. Even if the lack of a structured system of statistical monitoring makes quantitative analysis difficult, we can enumerate a growing number of studies on immigration. Most, however, mainly deal with local realities (for a comprehensive review see the "Primo rapporto sull'immigrazione" of the Italian Commission for Integration).

Public opinion and the academic world are mainly interested in illegal immigration and in the labour force impact of legal and illegal inflows (see for example Natale-Strozza [1997], Venturini-Villosio [1998] and Gavosto-Venturini-Villosio [1999]).

In this work we branch out to study the effects of immigration on the sustainability of the welfare state in Italy. In particular, we are interested in the effects of immigration on the generational imbalance in Italian fiscal policy. To estimate the possible contribution of immigration to the long-term solvency of the public budget we use a set of generational accounts.

Generational accounting has been used to analyze the long-term sustainability of fiscal policy in a large number of countries, Italy included (see Sartor [1997], Franco et al. [1994] and ISAE [1999]). However, only three studies apply generational accounting to immigration policy: Ablett [1996] for Australia; Bonin-Raffelhuschen-Walliser [1998] for Germany; and AuerbachOreopoulos [1999] for USA. Our paper is the first attempt to implement this methodology for Italy.

Our finding is that immigration's contribution to the fiscal policy sustainability is never decisive. Sensitivity analysis confirms the results of the baseline case: for all the combinations of discount and growth rates considered, the net inflow of immigration in the next century does not bring the level of net taxes of living generations back down to that of future generations, that is, by generational accounting, the fiscal policy will remain unsustainable. Interestingly, immigration appears to be more decisive only if the immigrants' stay is stable. This result is in contrast with the current pension rule, which gives immigrants an incentive to repatriate upon retirement. 
The paper is organized as follows. The second section describes the methodology of generational accounting and the modifications introduced to separate immigrants from natives, describing the estimation procedure for the Italian and immigrant net tax profiles by age and sex, for public net wealth and for the level of indivisible public consumption. Sections 3 to 6 are dedicated to the demographic scenario and to the estimation procedures for age and sex profiles of taxes and transfers for Italians and immigrants. Sections 7 and 8 report the simulation results under different migratory, demographic and macroeconomic scenarios. Section 9 gives the results of the sensitivity analysis. Section 10 concludes.

\section{Generational accounting methodology}

Generational accounting was introduced in 1991 by Auerbach, Gokhale and Kotlikoff as an instrument for the long-term analysis of fiscal policy. Generational accounts show how much (in present value) present and future generations can expect to pay in net taxes over their lifetime. The condition that determines the sustainability of the fiscal policy is derived from the intertemporal government budget constraint. In particular, generational accounting tries to determine the present value of the primary surplus that the future generation must pay to government in order to satisfy the constraint if current fiscal policy remains constant for living generations. A fiscal policy is considered unsustainable or intergenerationally inequitable if the net payment of future generations is on average greater than that of the first living generation.

Generational accounting is not a general equilibrium model. It does not embody reaction functions, and therefore generational accounts cannot be considered as a tool for forecasting. Rather, they are "what if" projections to verify the compatibility of current fiscal policies with the expected demographic evolution, assuming the absence of bequest motives and liquidity constraints. For a critical analysis of the limits of the methodology, see Haveman [1994], Congressional Budget Office [1995], Buiter [1997] and Banks, Disney and Smith [1999].

To facilitate the comprehension of the results, in this section we provide a brief description of the calculation of generational accounts. First we show the methodology as developed originally by Auerbach, Gokhale and Kotlikoff [1991], and then we introduce the modifications needed to analyse the effects of immigration. For a more detailed analysis of GA see for example Auerbach-Gokhale-Kotlikoff [1991] and Congessional Budget Office [1995]. 
Generational accounting starts from the government intertemporal budget constraint as presented in equation (1):

$$
\sum_{s=0}^{D} N_{t, t-s}+\sum_{s=1}^{\infty} N_{t, t+s}=-W_{t}+\sum_{s=1}^{\infty} G_{s} \prod_{j=t+1}^{\infty}\left(\frac{1}{1+r_{j}}\right)
$$

where

$\sum_{s=0}^{D} N_{t, t-s} \quad$ is the present value of the net taxes of the living generations

$\sum_{s=1}^{\infty} N_{t, t+s} \quad$ is the present value of the net taxes future generations

$\mathrm{W}_{\mathrm{t}} \quad$ is the present value of public wealth

$\sum_{s=t}^{\infty} G_{s} \prod_{j=t+1}^{\infty}\left(\frac{1}{1+r_{j}}\right)$ is the present value of indivisible public goods

By "net taxes" we define the sum of all taxes an individual pays net of all transfers he/she receives from the central and local administration during his/her lifetime. The first term on the left-hand side of equation [1] measures the net taxes of living generations in present value at time $(t)$. Life expectancy is 90 years. The oldest living generation is born in $t$ $D(D=90)$ and is expected to die at the end of the year $t$. The youngest generation is born in $t$ and is expected to die in $t+90$. Equation [2] shows that the present value of the net taxes of the generation born in $k\left(N_{t, k}\right)$ is calculated by summing the average net taxes paid in each year $s\left(T_{s, k}\right)$, from $t$ to $k+D$, by a member of generation $(k)$, discounted at rate $r_{j}$ and multiplied by the number of living individuals of generation $k$ in year $s\left(P_{s, k}\right)$. If $t<k$, the sum starts from $k$ (year of birth); otherwise, from $t$, the base year .

$$
N_{t, k}=\sum_{s=\max (t, k)}^{k+D} T_{s, k} P_{s, k} \prod_{j=t+1}^{s}\left(\frac{1}{1+r}\right)
$$


$W_{t}$, the first term of the right-hand side of equation [1] is the government's net wealth at time $(t)$. The second term of the right-hand side of equation [1], $G_{t}$, is the present value of current and future indivisible public goods, i.e. goods not assignable to people on the basis of age, sex and citizenship (for example: expenditures for public order or defence).

The degree of fiscal imbalance we refer to in the rest of the paper $\left(\varphi^{\text {tot }}\right)$ is defined as the ratio between the youngest living-generation individual's net taxes, adjusted for economic growth and the first future-generation individual's net taxes. Usually generational accounting posits that each member of future generations will bear an equal proportion of the burden needed to satisfy the intertemporal budget constraint, not considering the economic growth rate. The index of fiscal sustainability is thus:

$$
\varphi^{t o t}=\frac{G A_{t, t+1}}{G A_{t, t}(1+g)}-1
$$

with

$$
G A_{t, t}=\frac{N_{t}}{P_{t,}}
$$

and

$$
G A_{t, t+s}=\frac{-W_{t}+\sum_{s=t}^{\infty} G_{s} \Pi_{j=t+1}^{\infty}\left(\frac{1}{1+r_{j}}\right)-\sum_{s=0}^{D} N_{t, t-s}}{\sum_{s=1}^{\infty} P_{t+s, t+s}\left(\frac{1+g}{1+r}\right)^{s-1}}
$$

where:

$N_{t, t} \quad$ net taxes of the generation born in $t$.

$P_{t, t+s} \quad$ number of people in the generation born in $s$.

$P_{t, t} \quad$ number of people in the youngest living generation. 
The current fiscal policy is sustainable and intergenerationally equitable if $N_{t, t}$ is equal to $N_{t, t+1}$, net of the growth of the economy

\subsection{Generational accounting and immigration}

Following Bonin, Raffelhuschen and Walliser [1998], immigration can be introduced by splitting the first and second terms of equation [1] into those attributable to immigrants and those attributable to natives, as in equation [5]:

$\sum_{s=0}^{D} N{ }^{i t a}{ }_{t, t-s}+\sum_{s=0}^{D} N{ }^{s t r a}{ }_{t, t-s}+\sum_{s=1}^{\infty} N^{i t a}{ }_{t, t+s}+\sum_{s=1}^{\infty} N^{s t r a}{ }_{t, t+s}=W_{t}+\sum_{s=t}^{\infty} G_{s} \Pi_{j=t+1}^{\infty}\left(\frac{1}{1+r_{j}}\right)$

In equation [5] $N_{t, k}^{i t a}$ represents the present value of the net taxes of the Italians born in $k$. $N_{t, k}^{\text {stra }}$ represents the present value of the net taxes of the immigrants in Italy at time $k$. We consider as Italians: natives, first generation who arrived before age 15, and Italian-born children of immigrants. Only those who came to Italy after the age of $15^{\text {责 }}$ are considered to be immigrants.

The contribution of immigration to reducing the intergenerational imbalance of current fiscal policy is then calculated by comparing the value of the $\varphi$ index with and without immigrants. This computation is a questionable point ${ }^{3}$. Here we follow Auerbach and Oreopoulos [1999] and proportionally adjust some combination of taxes and transfers until the intertemporal budget constraint of equation [5] is satisfied. Then we derive the degree of intergenerational imbalance. In this way we can explicitly take account of the effects of changes in the mortality rate for both natives and immigrants.

\footnotetext{
${ }^{1}$ In calculating $N_{t, t}$ and $N_{t, t+l}$, GA methodology distinguishes male from female. To simplify the notation this distinction is not shown in equations[1],[2] and [3].

${ }^{2}$ The young immigrants are considered as Italians: the only justification for the immigrants' different age profile of tax and transfers is differences in education and language proficiency, but if immigrants attend school in Italy this gap should vanish.

${ }^{3}$ For a detailed discussion see Auerbach and Oreopoulos [1999].
} 


\section{The demographic scenarios}

Immigrants now make up about $2 \%$ of the total population of Italy, quite low by European Standards. However, the share will grow owing to continued immigration and the very low fertility rate of natives.

Projecting the current annual inflow of immigrants and the observed fertility and mortality rates of natives, Italy's population would shrink from 60 million today to 38 million in 50 years and 1 million in 200 years. In this context, supposing that the yearly inflow of immigrants is about the same as in the past, the share of immigrants in the total population will be $8 \%$ in 100 years, the same level currently observed in Germany.

Because of the great dependence of estimation results on demographic hypotheses, we develop three demographic scenarios (see graph 1) derived from high and baseline scenarios presented by Istat in 1996. These estimates are truncated in 2050 . We have extended the projection horizon to 2200 and we also take into account the different dynamics of the immigrant and native populations.

\section{Graph. 1: Demographic scenarios}

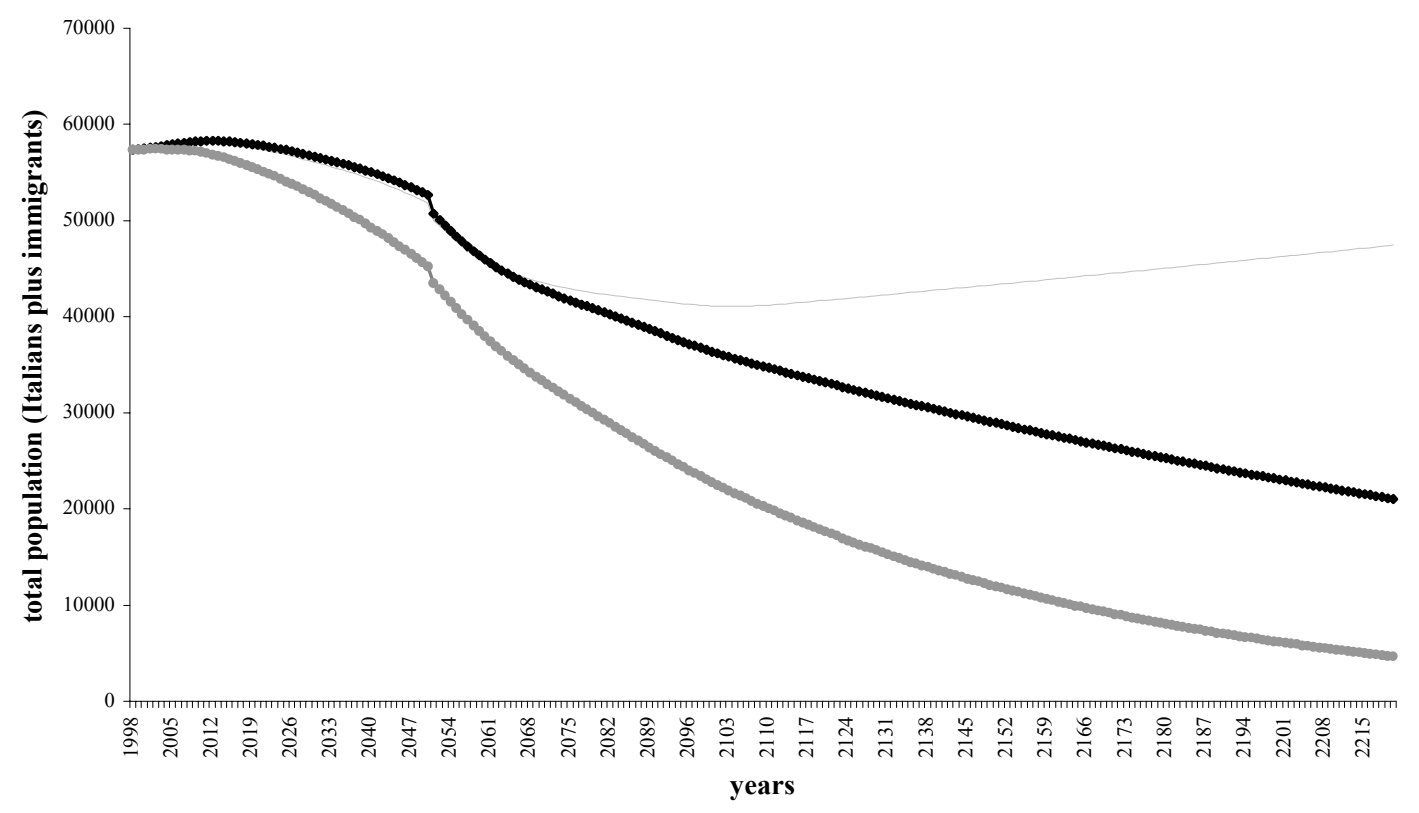

\begin{tabular}{|ll|}
\hline & high demographic scenario \\
middle demographic scenario \\
low demographic scenario
\end{tabular}


To extend the demographic estimates, we consider a gradual rise in the total fertility rate of the baseline scenario from 1.2 to 1.8 children per woman. As a result the population shrinks to an estimated 22 million at the end of the period. We hypothesized yearly immigration of 56,000 which brings the share of immigrants to $6.25 \%$ in 2050 and to $20.26 \%$ in 2200 .

The lower scenario assumes the total fertility rate will rise only to 1.4 children per woman after 2050. The immigrant inflow is assumed to decrease to 35,000 a year. These assumptions result in a population of 5 million in 2200 with the immigrant share at $47 \%$.

Finally, the high scenario describes a situation in which the total fertility rate rises steadily to 2.1 children per woman. This yields a population of 45 million at the end of the period. With yearly immigration of 76,000 individuals, the share of immigrants will be $8.5 \%$ of the population in 2050 and $14 \%$ in 2200.

In the three scenarios, the fertility rate of the first generation of immigrants is posted at 1.2 children per woman. We suppose, in keeping with disruption theory, that the difficulties of social and economic integration impede reproduction behaviour on the part of the immigrants (for a survey of the debate on the fertility of immigrant women see Blau [1991]). The reproductive behaviour of the second generations is assumed to be the same as for native Italians.

\section{How much do Italians contribute?}

In this section we describe the estimation procedure of the age and sex profiles of taxes and transfers for Italians and immigrants. The total expenditures and revenues are derived from the public sector accounts ("Conto Consolidato delle Amministrazioni Pubbliche 1998") and from the "Relazione Generale sulla situazione economica del Paese 1999". We distinguish expenditures and revenues by economic function (as in Table 1) and then we assign them according to age, sex and citizenship on the basis of the profiles derived from the available sample surveys ${ }^{1}$.

Graphs 2 and 3 display the sex and age profiles of social security contributions, direct and indirect taxes.

\footnotetext{
${ }^{4}$ An appendix with a more detailed review of the data sources is available from the author.
} 
Graph. 2: Tax age-profile: Italian males, 1998

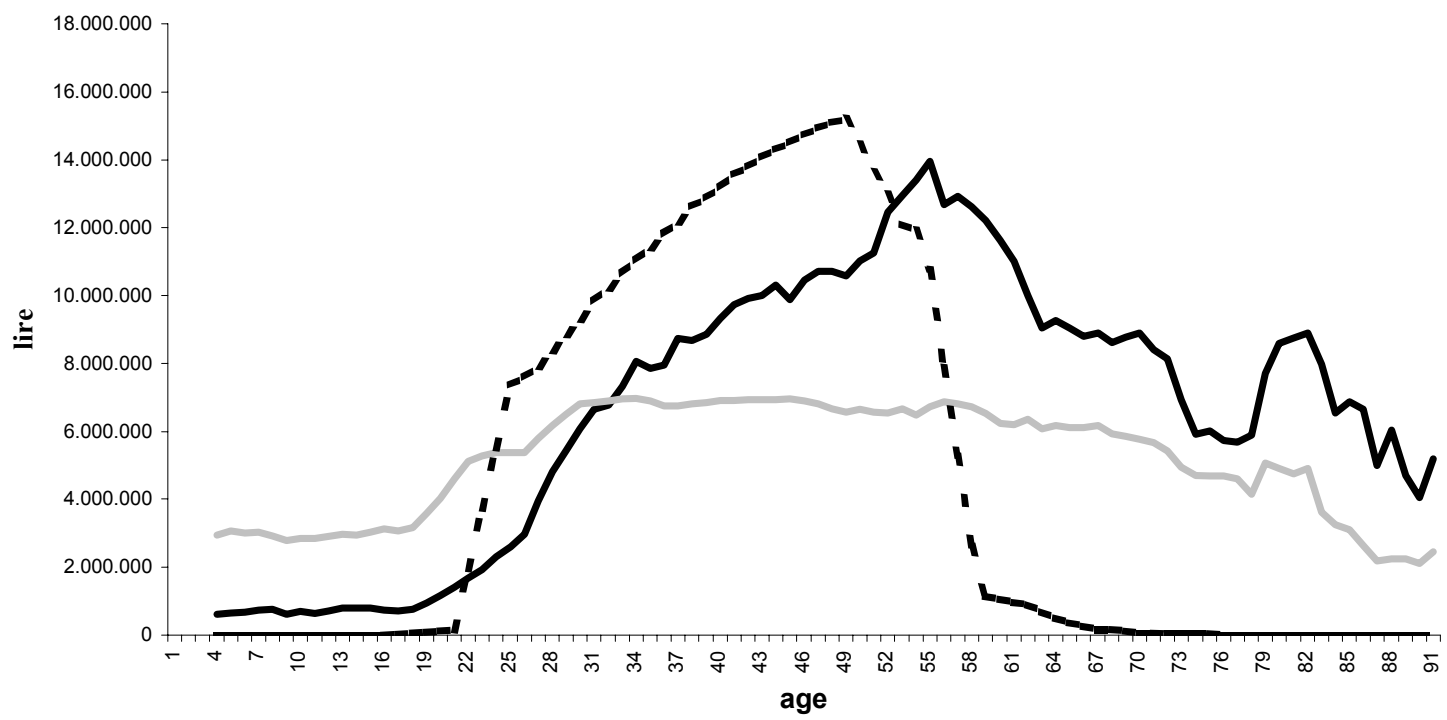

Graph. 3: Tax-age profile: Italian females, 1998

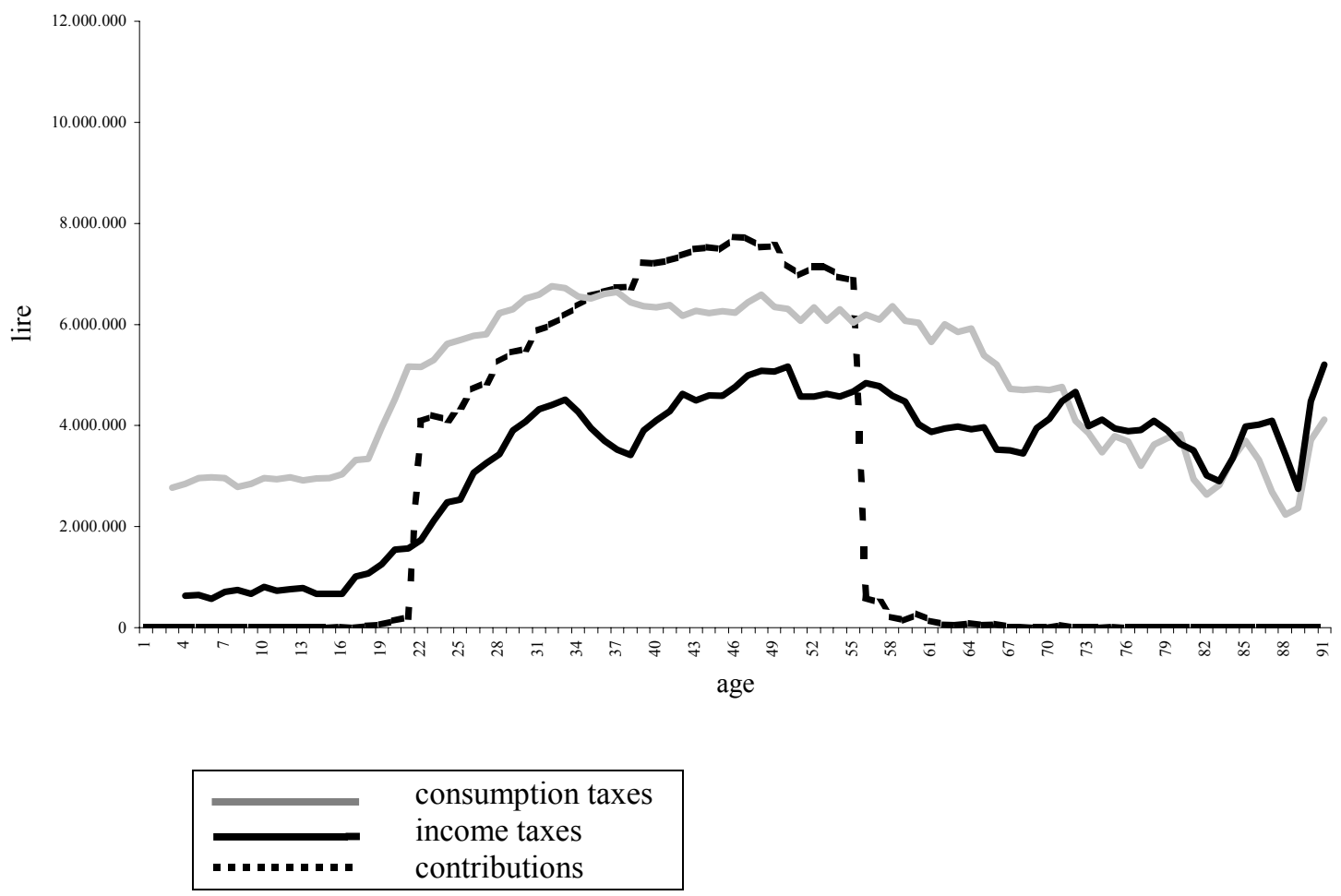


Social security contributions comprise payroll taxes and unemployment contributions. The profile follows the typical life cycle earnings path: zero in childhood, high during working age, and a much lower level in old age. The profile peaks around the age of 50 for both men and women. The lower participation rate of women explains the different average level between sexes

The direct tax profile includes the personal income tax (Irpef), the company tax (Irpeg), the flat-rate tax on interest income and capital gain and other minor levies. The income tax profile is relatively low up to age 50, when on average income and capital gains taxes increase, reflecting the life cycle path of wealth accumulation. The maximum direct taxation is observed at the end of the career when the average wage is highest and the stock of capital is increasing. At this age direct taxes average 14 million lire for men and 5 million lire for women.

Indirect taxes comprise VAT, a regional tax on productive activity (IRAP), petroleum excise taxes and other minor levies on consumption. The indirect tax profile does not show great variability with age. Its maximum is in middle age (7 million lire for men and 6 million lire for women). This presumably reflects the assumptions made in estimating the profiles. The Istat survey on consumption [1995] registers the amount of consumption at the household level.

The main expenditure profiles are health, education, social assistance and social security transfers. Their sex and age profiles are shown in Graphs 4 and 5.

\footnotetext{
${ }^{5}$ This situation in reality is expected to change in the future. The growing participation of women will probably approximate the female to the male profile for wages and the same will happen to the age profile of contributions and income tax. However, generational accounts are not able to consider such cohort effects, because the profiles obtained from cross sectional data of 1998 are kept constant except for economic growth (the point is analysed in detail in Banks, Disney and Smith [1999]).
} 
Graph. 4: Transfer age-profile: Italian males, 1998

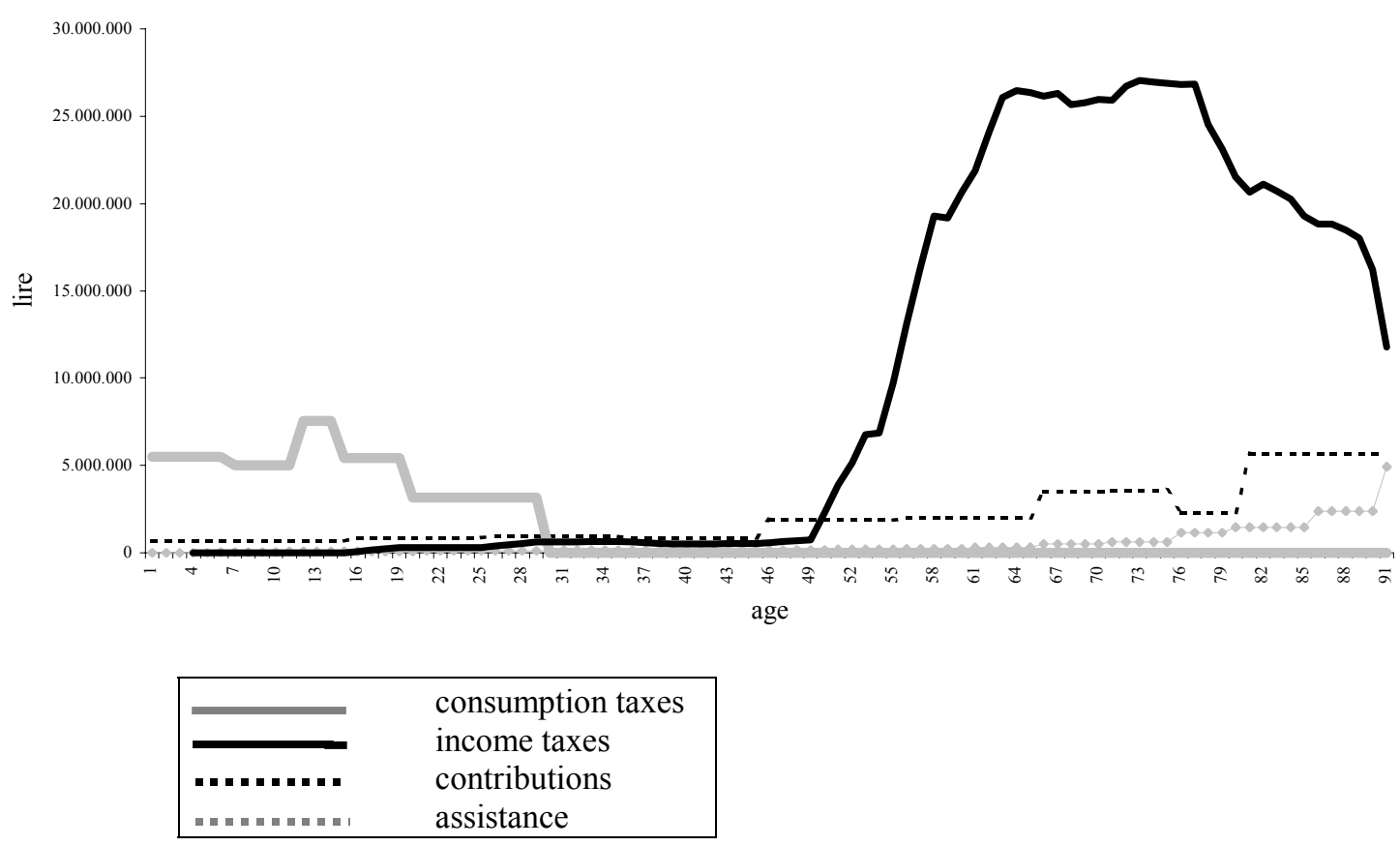

Graph. 5: Transfer age-profile: Italian females, 1998

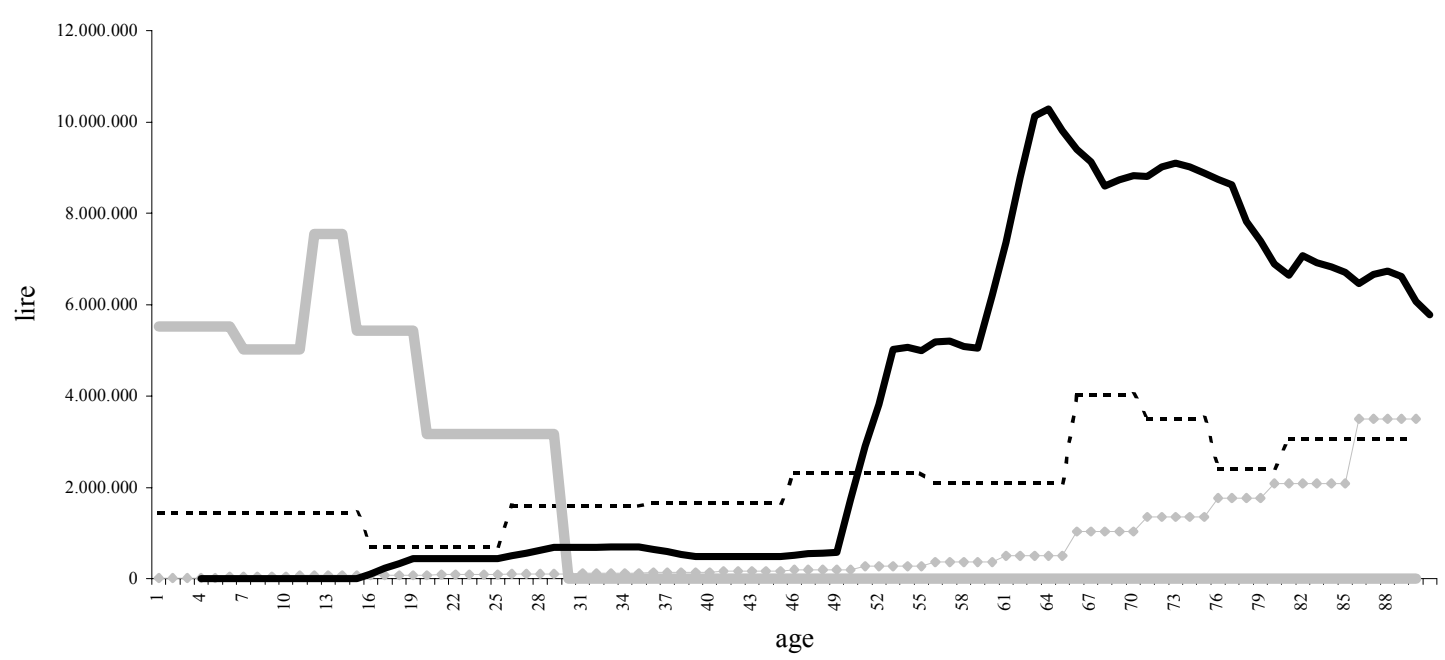

\begin{tabular}{|ll|}
\hline & $\begin{array}{l}\text { consumption taxes } \\
\text { income taxes } \\
\text { contributions } \\
\text { assistance }\end{array}$ \\
\hline
\end{tabular}


The public health transfer profile of men and women rises with age to a maximum in old age of 4 million lire a year. The age profile of educational transfers peaks in the last two years of compulsory schooling, then falls to zero. This profile is basically the same for men and women. Pension, unemployment, maternity, illness and accident benefits are counted together as social security transfers. Given women's longer life expectancy, the pension benefits of men peak ten years before those of women. The factors in this difference are men's greater labour market participation and their higher average earnings. Finally, social assistance transfers comprise civil disability, veteran's pensions, welfare benefits and labour orientation expenditures. As expected, they rise with age, and they are higher for women.

The net fiscal position of the individual with respect to age is depicted in Graph 6 where we put together all taxes and transfers. Each point represents the difference between all taxes paid and all transfers received in year $(t)$ by a representative individual of a certain age $(k)$ under the current fiscal policy.

Graph. 6: Net tax age-profile: Italians, 1998

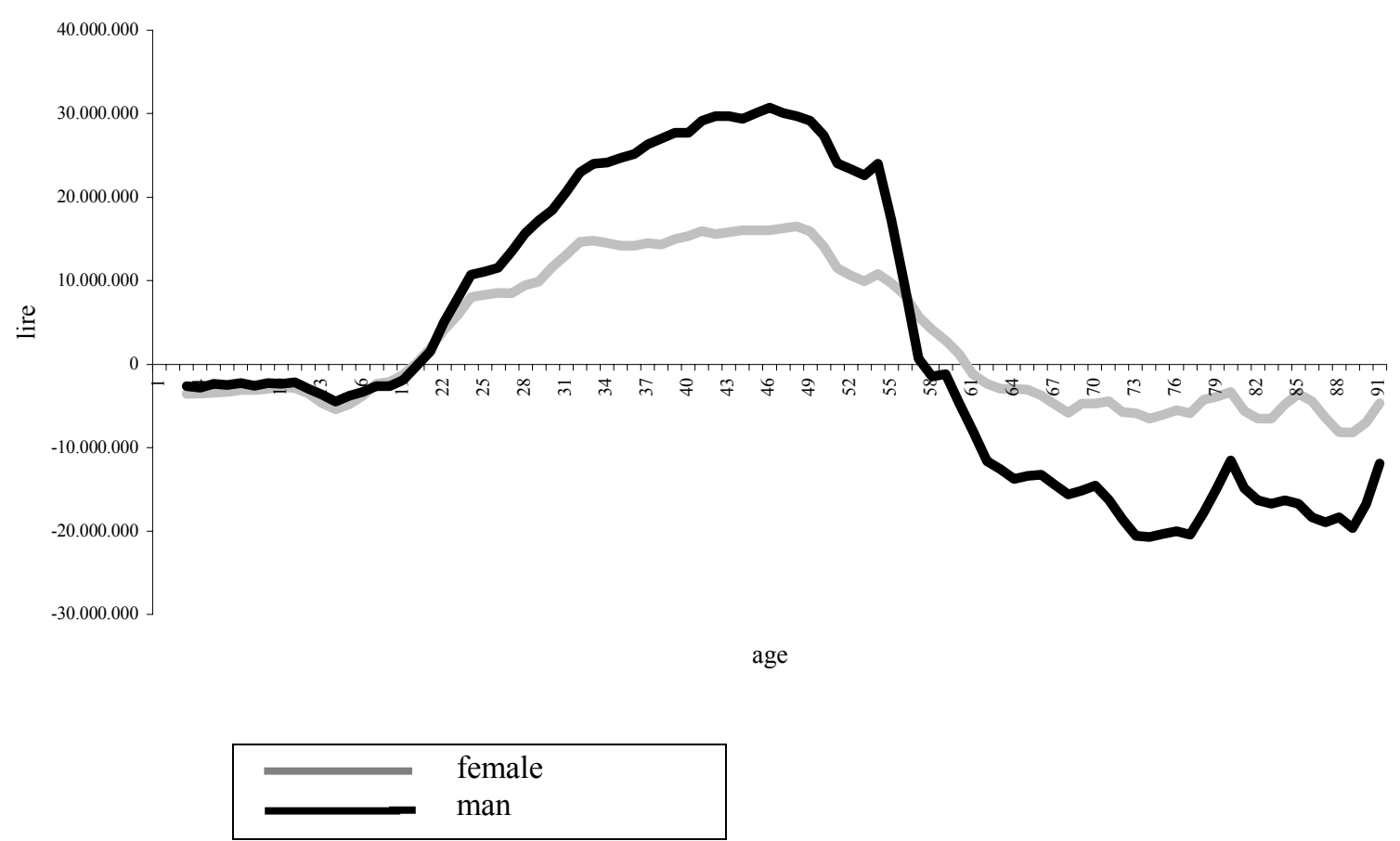

Early in life the main transfers are for health and education. During working age, taxes peak while education transfers go to zero and health transfers increase slowly. The average individual in this age-group is entitled to all the public transfers linked to work insurance 
programs and to the family, but because people are obliged to save for old age, they are net tax payers. Net transfers turn positive again in old age.

\section{How much do immigrants contribute?}

The Bank of Italy Survey and the Istat Survey, the two main sources of information used in this work for the estimation of Italians' net tax profiles, do not explicitly register immigrants. To compensate for this lack, we reconstruct age and sex profiles of immigrants indirectly. Rather than start with the aggregate value of taxes and transfers and allocate them by age and sex on the basis of our estimated profiles, we start from the few profiles available from administrative data and then measure the aggregate value of taxes and transfers attributable to immigrants.

In particular, the amounts of pension benefits, labour income taxes and payroll taxes are derived from profiles of immigrant workers registered with the National Social Security Institute (INPS). For consumption taxes we refer to a local survey. Finally, because of the lack of information, immigrants' non-social-security transfer entitlements under Law $286 / 1998$ were set equal to those of Italians ${ }^{6}$.

Graph. 7: Tax age-profile: Immigrant males, 1998

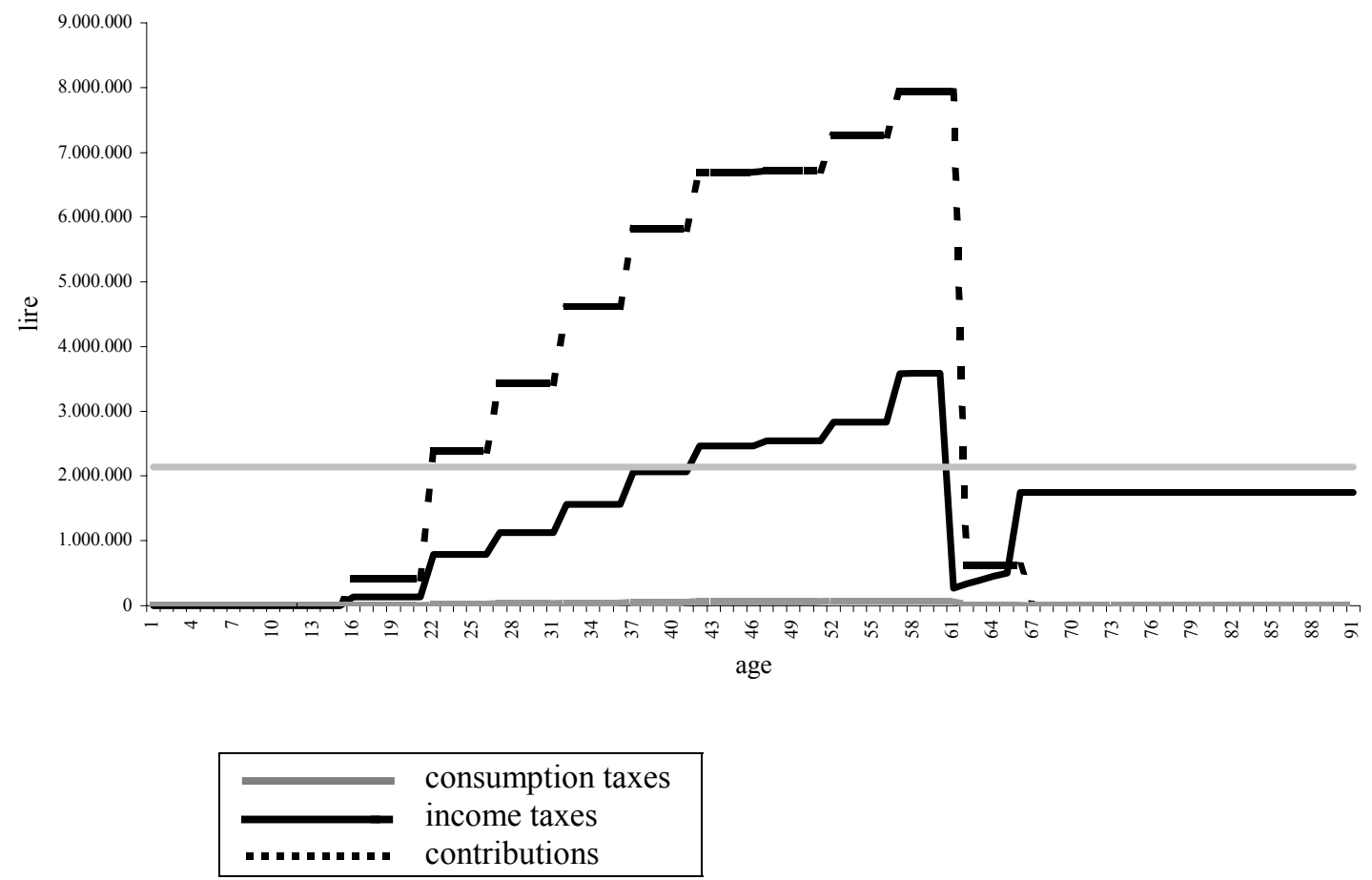




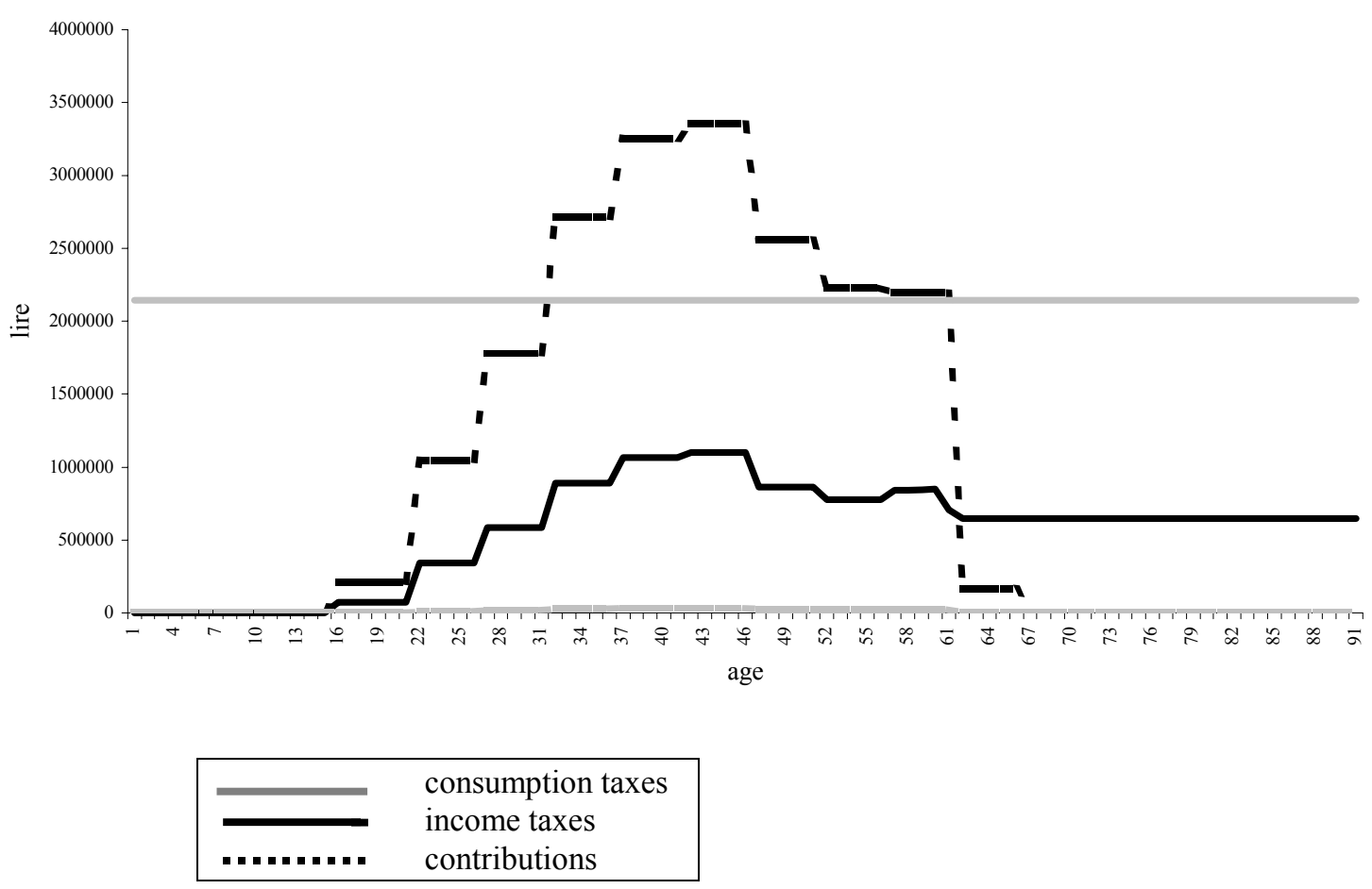

The income taxes and social security contributions of the immigrants follow the wage profile. For men, the peak for both is at age of 55-60; for women, between 40 and 50. The lower level of immigrants' taxes and transfers is presumably due to their lower participation rate; immigrants are often employed in unskilled jobs. Because their average income is lower and their saving higher than Italians (emigrants' remittances are in fact a significant item in many underdeveloped countries' balance of payments) their consumption taxes are also regularly lower: on average, only about 2.1 million lire.

\footnotetext{
${ }^{6}$ An appendix with a more detailed review of the working hypotheses is available from the author on request.
} 
Graph. 9: Transfer age-profile: Immigrant males, 1998

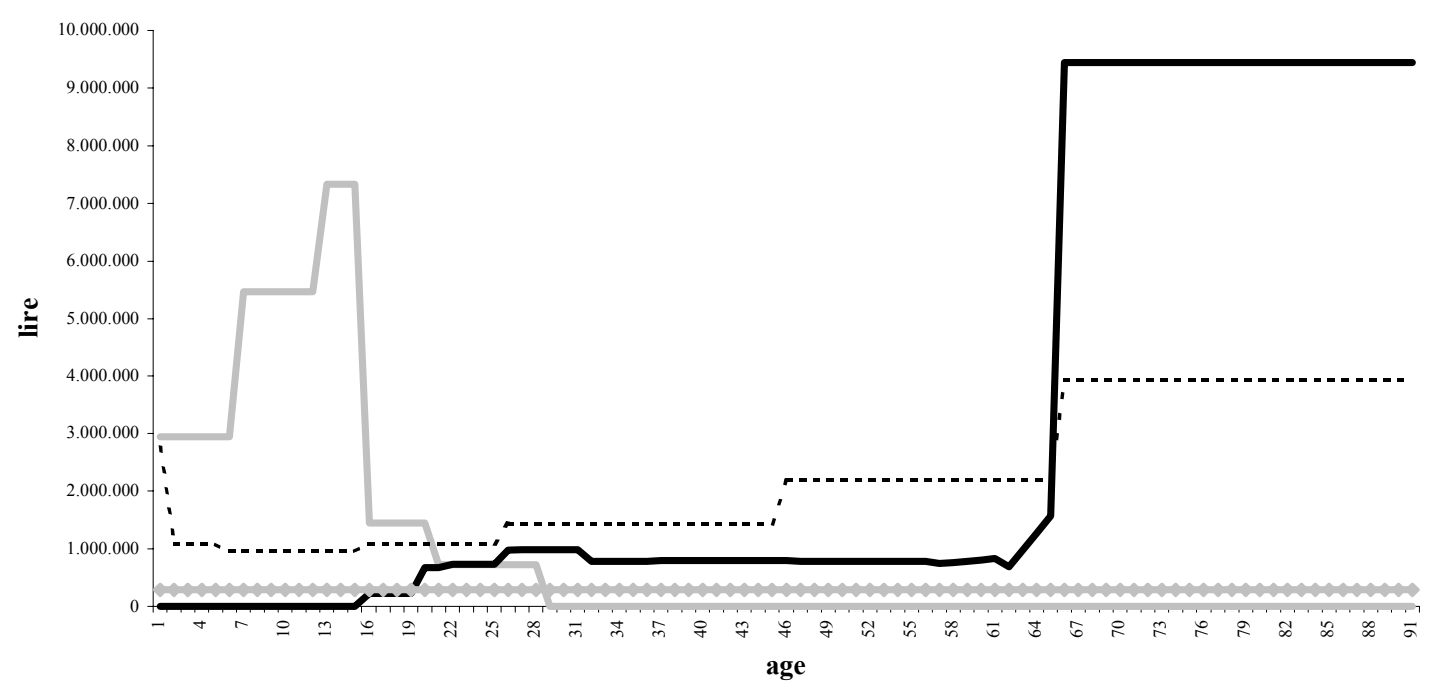

\begin{tabular}{|ll|}
\hline & $\begin{array}{l}\text { education } \\
\text { social security } \\
\text { health care } \\
\text { assistance }\end{array}$ \\
\hline$\ldots+\ldots+1$ &
\end{tabular}

Graph. 10: Transfer age-profile: Immigrant females, 1998

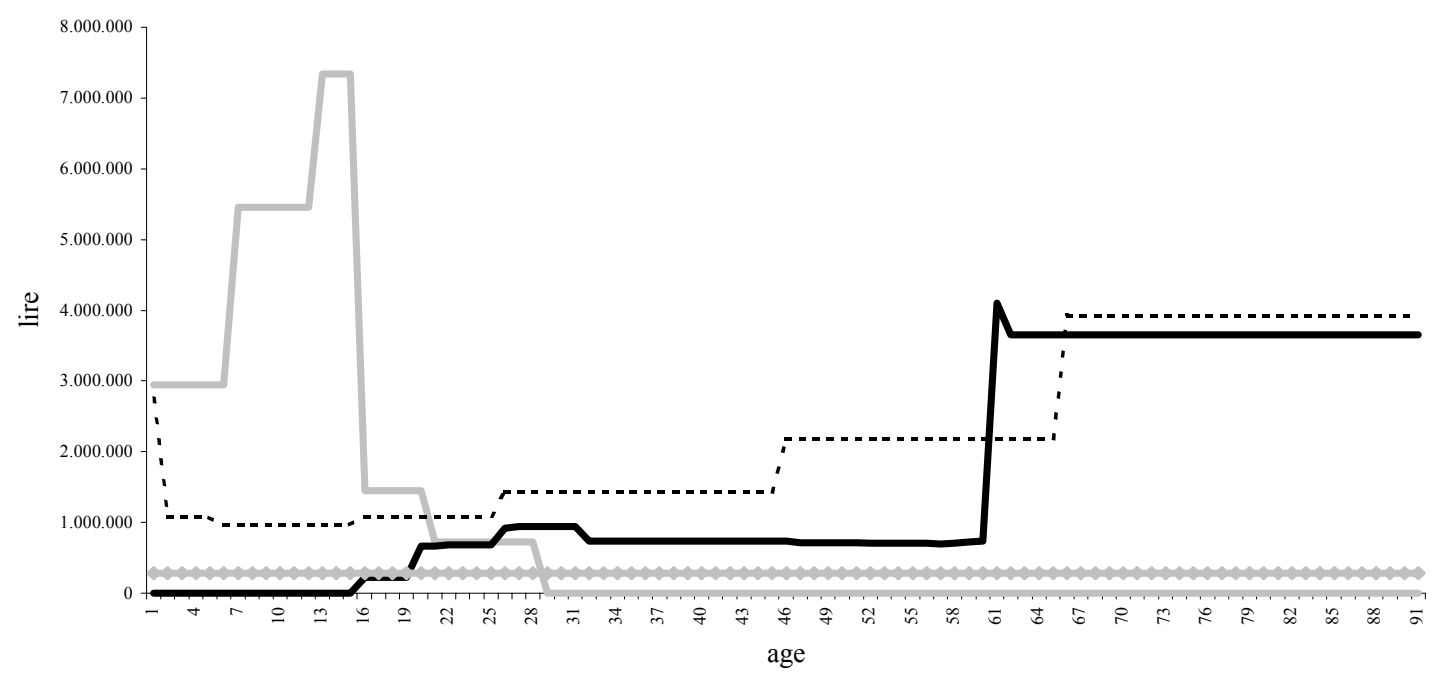

education
social security
health care
assistance


The health profile, for which data are not available, has simply been posited as identical to Italians, No difference is observed in educational transfers towards children of compulsory school age. However, the rate of immigrants' attendance of high school and university is lower ( $25 \%$ versus $60 \%$ for high school, $9.5 \%$ versus $20 \%$ for university). Social security transfers to immigrants prove to be about one third of those to Italians.

There are no retired immigrants in Italy yet, but this does not mean that there will not be in the near future, so the pension profiles have been estimated by using the wage-age profile and participation rate and applying the rule instituted by the Dini government reform.

As for non-social-security transfers, under Law 286/1998 immigrants are entitled to all the insurance provisions linked with employment positions in Italy. The differences in the age profiles of these transfers are thus due to differing shares of workers in each cohort and to different incidence of insured events on the working immigrant population. In particular, the data on unemployment indicate that the number of immigrants registered with the Employment Service is 177,000 , or $6 \%$ of all immigrant workers. By imputing to each unemployed immigrant the same average transfer attributed to Italians, we obtain an age profile similar to Italians' in shape (the maximum transfer is around age 30 for both), but higher in terms of the average per cohort transfer (at the age of 20 the transfer for a male is about 600,000 lire). This considerably higher percentage of unemployed among immigrants is explained in part by the fact that registration entitles foreigners to renew their residence permits, so that people who work off-the-books or who actually do not want to work at all register anyway.

The remaining components of social security transfer, i.e. accident, maternity and illness benefits, were approximated to the percentage of immigrants in the total labour force; they amount to less than 200,000 lire per capita. Actually, this method probably underestimates the real size of accident transfers and overestimates maternity and illness benefits. Because immigrants are mostly employed in the less safe occupations, the number of work accidents is higher than for Italians (the immigrants are $1.9 \%$ of the population but account for $3.69 \%$ accidents) so their average transfer (on this head) is probably higher. The fear of losing one's job, meanwhile, will be a strong disincentive against immigrants

\footnotetext{
${ }^{7}$ Some epidemiological works observed that immigrants who decide to leave their country tend to be in good health (Costa-Lemma [1994]). Thus at least initially, immigrants' voluntary consumption of health care is expected to be lower than Italians'. However their poorer hygiene and working conditions and their lesser concern with preventive measures_would appear likely to reduce this advantage rapidly.
} 
absenting themselves for long, so the real size of this kind of transfer is probably underestimated. In any event, the lack of data obliges us to resort to this approximation, and the two errors may be offsetting. Finally the disability transfers, which are also 200,000 lire per capita, are attributed without distinction on the base of the age to both men and women.

Theoretically, the social security transfers must also included family allowances, an item that will gain weight, as immigration for purposes of family reunification is growing. Nevertheless we were not able to consider it, because information on the composition and income of immigrants' families is lacking.

As with disability transfers all welfare transfers, i.e. those not deriving from job-related insurance positions, were attributed to immigrants as a fixed quota without considering age differences. Their profile thus appears artificially flat, and equal for men and women, at 385,000 lire.

Graph. 11: Net tax age-profile: Immigrants, 1998

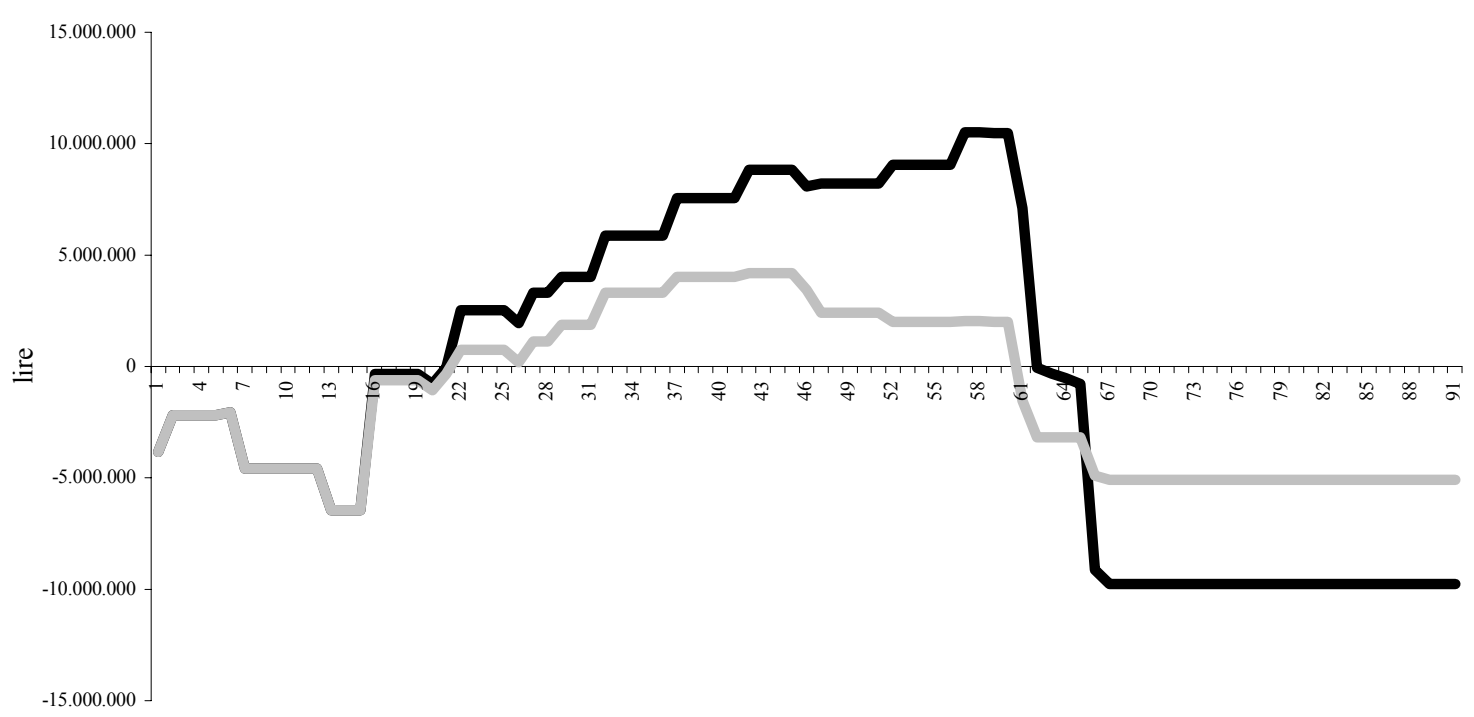

age

Overall, the average immigrant male is a net tax-payer from the age of 15 to the age of 60 (see Graph 11). The highest net contribution (of about 11 million lire) comes around age 
50 , while the highest level of net receipts ( 9 million lire) comes at age of 65 . For the average immigrant woman the maximum contribution is at age 40-45 and is about 4 million lire, while the largest net benefits receipts come at age 15 and amount to 5 million lire). The determinants of these results are mainly education and unemployment insurance expenditures.

\section{The net taxes of Italians and immigrants}

The present value profile of immigrants' and Italians' net tax payments estimate how much a representative individual at each given age can expect to pay over the rest of his/her life span. Taxes and transfers are assumed to grow at the same rate as the economy. The discount rate is $4 \%$. The profiles here are assumed to be fixed in time aside from economic growth with the exception of the pension transfers. With the help of the simulation model provided by Ferraresi and Fornero [1999], it was possible to take the effects of the 1992 and 1995 pension reforms into account. Any point in Graph 12 represents the present value of net taxes at a given age and for a give fiscal policy.

The average Italian male is a net tax payer in terms of present value of all life net taxes until age 50, then he becomes a net transfer recipient. By the same definition the average Italian woman is a net tax payer until age 40 (Graph 13).

Graph. 12: Net tax present value-profile: Italians, 1998

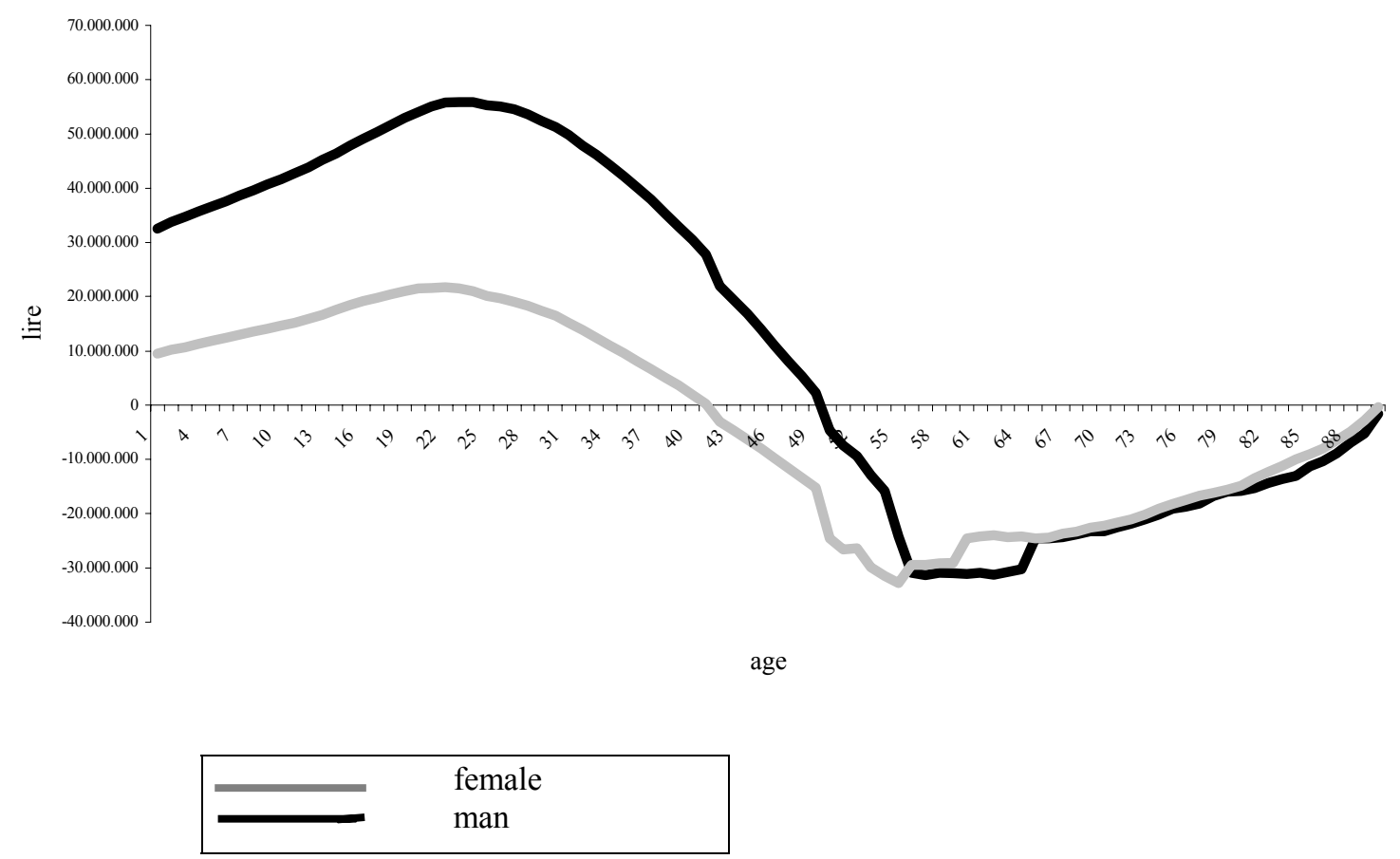




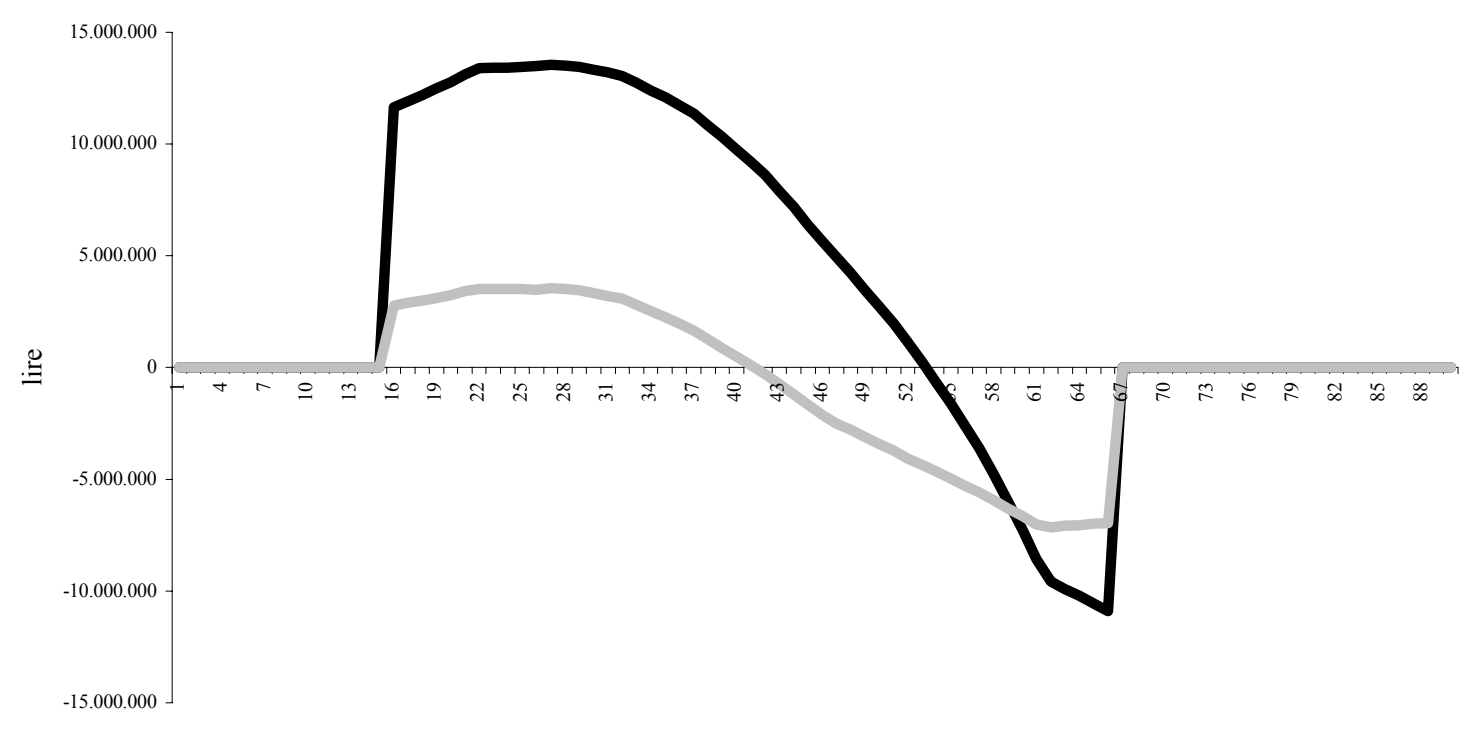

age

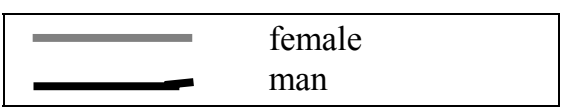

The present value payments of the average immigrant's net taxes is lower, and it becomes negative later in life. Thus immigrants who arrive in Italy before age 55 if male and 45 if female are a net resource for the Italian welfare state. The total amount of taxes and contributions they are to pay for the rest of their life is greater than the total amount of expected welfare transfers. The likely sign of the immigrants' contribution to the sustainability of the Italian welfare state is thus positive. We can observe from Graphs 14 and 15 that about $80 \%$ of today's immigrants are of an the age at which they figure as net tax payers. 
Graph. 14: Age-structure and net tax present value-profile: Immigrant males, 1998

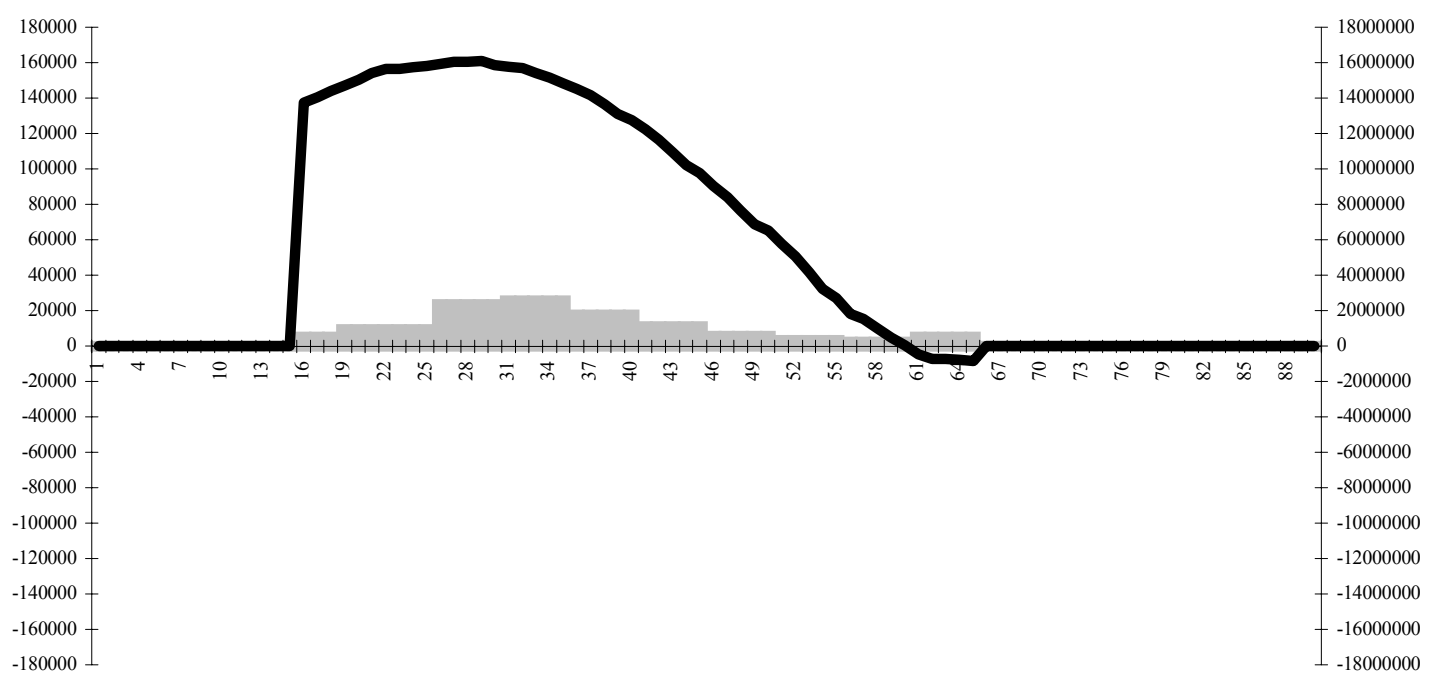

Graph. 15: Age-structure and net tax present value-profile: Immigrant females, 1998

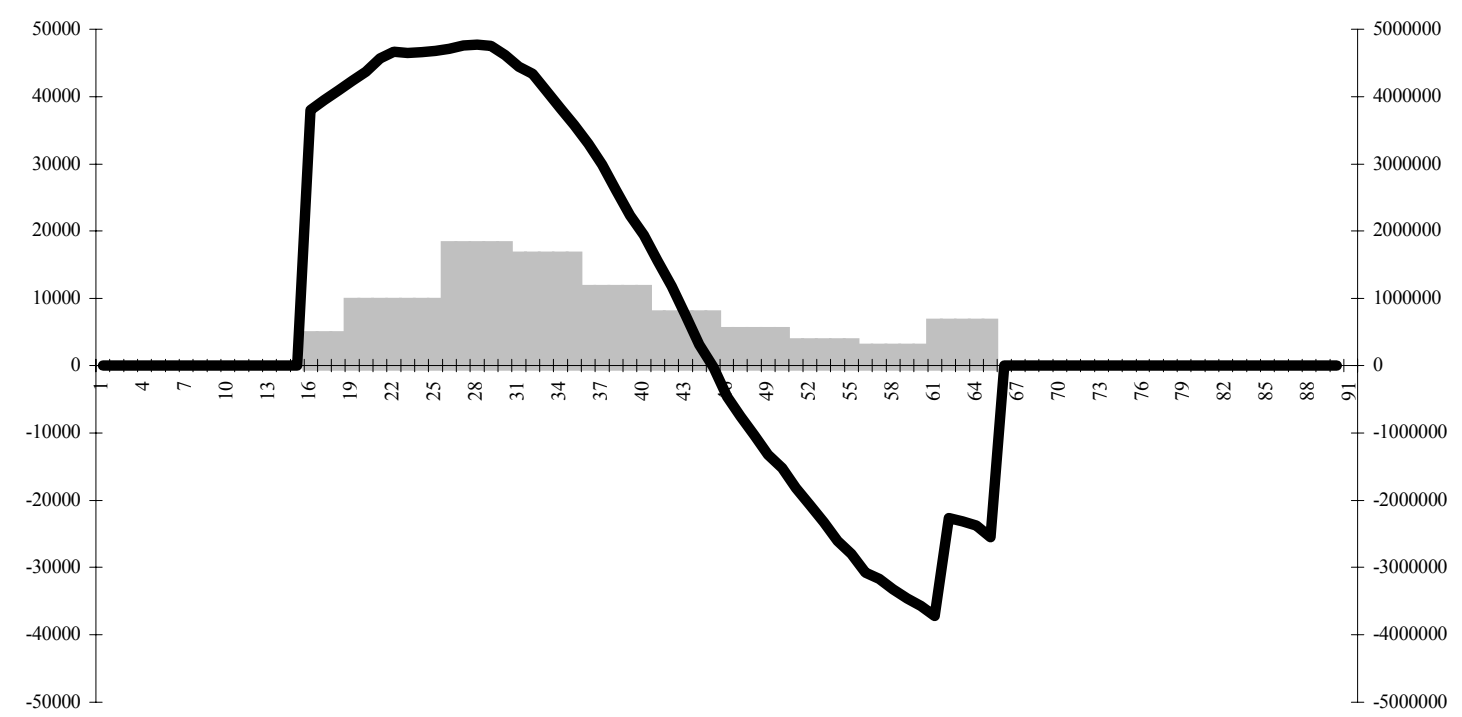

\begin{tabular}{|ll|}
$\square \square$ & age structure \\
& female \\
\hline
\end{tabular}




\section{Results in the baseline case}

The results of the simulation are given in Table 2. In the middle and the low demographic scenarios the current fiscal policy, going by the definition of generational accounting, is unsustainable. In other words, the current fiscal policy is intergenerationally unbalanced: future generations are called to pay more net taxes than the last living generation. Under the optimistic demographic scenario, the imbalance is near zero. This result underscores the fact that one of the main causes of the unsustainability of the current fiscal policy is the aging of the population.

Immigrants help to right the generational imbalance in all the non-conservative demographic scenarios considered. In the middle scenario, the yearly inflow of 50,000 reduces the imbalance by 6 percentage points; in the low scenario, immigration reduces the intergenerational imbalance by 8 points. In terms of net taxes, future generations are called to pay about 15 million lire more than the last living generations in both cases. The data show also that the larger the inflow, the larger the contribution to the reduction of the imbalance.

In our simulations we chose to link the amount of immigration with the Italian socioeconomical environment (see Table 3). Larger inflows $(76,000)$ were thus associated with the sharpest recovery of the native fertility rate. Conversely, the smaller inflow $(30,000)$ was associated with a more moderate recovery in fertility.

In none of scenarios, however, is the contribution of immigration sufficient, by itself, to right the fiscal imbalance and make current fiscal policy sustainable.

In order to enrich the informational power of our results, we calculate the increase in taxes (contributions excluded) necessary to comply with the intertemporal budget constraint. This second measure is useful to calculate the size of a tax increase capable by itself of restoring intergenerational balance. The increase is smaller than the degree of the imbalance because it is not expressed in present value but in terms of percentage increase in the taxes paid by the average individual at each age. The largest burden is borne by people who pay the most taxes, i.e. men of working age. A fiscal policy adjustment based on cutting transfers to future generations would bear more heavily on women and the retired age-groups. 


\section{Three migration scenarios}

The simulations presented above assume that the immigrants spend their entire life in Italy. The empirical evidence, however, does not support such an assumption. A significant number of immigrants prefer short stays. To make our assumptions more realistic, we shape two other migration scenarios: in one, immigrants stay in Italy for 5 years; in the second, they remain for their entire working life and repatriate at retirement.

The shorter the stay in Italy, the smaller their positive contribution to the reduction of the intergenerational imbalance (see Table 4). In the middle demographic scenario, if immigrants decide to establish themselves permanently in Italy they reduce the generational imbalance by 6 percentage points. If they decide to repatriate at retirement, the gain falls to 4 percentage points. Finally, if their stay lasts only 5 years, their contribution is only 0.2 percentage points.

Under the current migration policy, it is far more advantageous for Italy to assimilate the immigrants. If they stay only a few years it is unlikely that they will have children so they would not contribute to the nation's future population growth. And if their stay is short, the taxes they pay might just barely repay the costs of initial reception and accommodation upon arrival.

Less intuitive is the result of the simulation based on the second scenario, under which the immigrant spends his working life in Italy and repatriates at retirement. Perhaps surprisingly, this proves to be less advantageous to the Italian fiscal balance than permanent residence. Old age is a period in which the average person is a net recipient of public transfers, especially for health services, and since many transfers are tied to residence, if an immigrant repatriates Italy should save money. However, because most immigrants come from countries with which the Italian social security system does not have conventions, when they repatriate they are entitled to the amount of their contribution capitalized at an annual nominal rate of return of $5 \%$. This is more favourable than the current implicit yield of the Italian pension scheme.

\section{Sensitivity analysis}

In this section we test the sensitivity of our results to the hypotheses made on discount rate and growth rate of the economy. Different hypotheses on the discount rate influence the 
net taxes of the various generations (the greater the differential with respect to the growth rate of the economy, the lower the present value of the net per capita taxes attributable to future generations) and affect the speed at which indivisible public consumption grows (the larger the differential between $r$ and $g$, the slower the growth) in an opposite way. The final effect depends so from the relative intensity of the two variations.

As we have seen before, the growth in the tax rate necessary in order to eliminate the intertemporal imbalance in the baseline demographic scenario and macroeconomic scenario (the middle scenario) is about $2 \%$.

An increase in the interest rate of one percentage point leads to an increase of this pergentage to $8.91 \%$ showing the prevalence of the effect of the reduction of present value of the net per capita taxes attributable to future generations on the effect of opposite sign on the public consumption expenditures (see Table 5).

For the same reason, a decrease of the interest rate of one percentage point leads to a tax growth percentage of $-0.11 \%$. It is worth noting that in this last case as under the high demographic scenario with low differential among interest rate and rate of growth, the current fiscal policy is not unbalanced toward the living generations anymore. The intertemporal imbalance degree appears in fact to be negative. This would allow to a reduction of the tax burden of the future generations.

The relative increase in the rate of growth of the public expenditures prevails instead in the low demographic scenario. A decrease in the interest rate causes in fact an increase in the tax growth required to recover generational balance.

\section{Conclusion}

This paper assesses the contribution of immigration to the intergenerational sustainability of Italian fiscal policy, using the generational accounting methodology, which is based on four main assumptions (Haveman [1994]):

1. invariability of fiscal policy for current generations;

2. the obligation of future generations to bear the entire burden of satisfying the intergenerational budget constraint, and the non-admissibility of default;

3. complete description of individual behaviour by the life cycle theory; 
4. no effects of general economic equilibrium.

Generational accounts are not forecasts but only "what if" projections, indications of what would happen if nothing changed in fiscal policy for living generations.

Some recent empirical studies for Italy analyze the effects of immigration on the sustainability of welfare state program from a merely numerical point of view (see for example Valentini [1999]), on the thesis that the main causes of the feared future unsustainability of our welfare system are population aging and the decline in fertility. Then, formulating several scenarios on migratory inflows, they seek to estimate the effects of immigration. This approach is over-simple, because it implicitly assumes that Italians and immigrants have the same age profiles for taxes and transfers and differ only in the age and gender structure of the population.

Realistically, however, we cannot ignore the fact that immigrants tend to have the lowest grade jobs (as is shown by the econometric study of Venturini and Villosio [1999a]). Their income is lower than Italians' and so are their taxes. Furthermore, their access to welfare benefits can be expected to differ from that of Italians, because of differences in rules and other obstacles to participation in entitlement programs (the poverty stigma, language barriers, etc.). Finally, immigrants often plan to repatriate, not to live the rest of their lives in Italy. This will surely produce some effect on the final amount of taxes they pay and transfers they receive.

The lack of data about immigrants prevents us from fully understanding these differences. Nevertheless, our results show that immigrants in Italy can reduce the expected burden of future generations; their presumed contribution to welfare state sustainability, although never decisive, is always positive. In the baseline case, yearly immigration of 50,000 people reduces the degree of imbalance of our current fiscal policy by 6 percentage points. This means that at birth, the present value of the net taxes of the average member of the first future generation needed to satisfy the intertemporal budget constraint is 238 million lire, compared with 251 million lire on the hypothesis of no immigration.

The extent of the immigrants' contribution is highly dependent on the length of their stay in Italy. The longer the stay, the greater their contribution to sustainability. According to our simulations, a very short stay (under five years) would make the sustainability of the current immigration policy questionable. The contribution of immigrants, in this case, would be so small that it would scarcely be enough to cover the costs incurred for their initial 
reception. The five-year-stay scenario shows that the net taxes paid by immigrants barely cover their share of indivisible consumption. 


\section{REFERENCES}

ABLETT J. (1996), Generational Accounting in Australia, in AUERBACH A., KOTLIKOFF L.J., in LEIBFRITZ W. (1999), Generational Accounts around the world, The University of Chicago Press

AUERBACH A., GOKHALE J., KOTLIKOFF L.J. (1991), Generational accounting: A meaningful alternative to deficit accounting, NBER WP 3589

BANKS J., DISNEY R., SMITH Z. (1999), What can we learn about pension reform from generational accounts for the U.K., Institute for Fiscal Studies W99/16

BLAU F. (1991), The fertility of immigrant women: evidence from hight fertility source countries, NBER WP 3608

BONIN H, RAFFELHUSCHEN B., WALLISER J. (1998), Can immigration alleviate the demographic burden?, mimeo

BUITER W. (1997), Generational accounts, aggregate saving and intergenerational distribution, Economica n.64

CONGRESSIONAL BUDGET OFFICE (1995), Who pays and when? An assessement of generational accounting, http://www.cbo.doc

COSTA G., LEMMA P. (1999), Immigrazione straniera, quale profilo di salute?, in corso di stampa

FERRARESI P.M., FORNERO E. (1999), Money worth measures for the Italian Social Security System, CeRP Working Paper.

GAVOSTO L., VENTURINI A., VILLOSIO C., (1999b), Do immigrants compete with natives?, Labour vol 13 n.3

HAVEMAN R. (1994), Should generational accounts replace public budgets and deficits?, Journal of Economic Perspectives

ISAE (1999), Rapporto trimestrale, Roma

ISTAT (1996), Previsioni demografiche, Istat

NATALE M, STROZZA S. (1997), Gli immigrati stranieri in Italia. Quanti sono, chi sono, come vivono?; Bari; Cacucci.

VENTURINI A., VILLOSIO C. (1999a), Foreign workers in Italy: Are they assimilating to natives? Are they competing against natives? An analysis by the SSA data set, Journal of Population Economics 
Table 1: Tax and transfer items

\begin{tabular}{|c|c|c|c|}
\hline EXPENDITURES & & REVENUES & \\
\hline & $\begin{array}{l}\text { Billions of } \\
\quad \text { lire }\end{array}$ & & $\begin{array}{l}\text { Billions of } \\
\text { lire }\end{array}$ \\
\hline PENSIONS & & INCOME TAXES & \\
\hline - old age & 264,599 & -irpef & 204,681 \\
\hline -disability & 4,528 & -irpeg & 43,131 \\
\hline -survivors & 55,347 & -ilor & 6,507 \\
\hline WELFARE & & $\begin{array}{l}\text {-proportional tax on investment income "tassa } \\
\text { sostitutiva" }\end{array}$ & 18,230 \\
\hline $\begin{array}{l}\text { "Social pensions" (Old } \\
\text { age poverty benefits) }\end{array}$ & 3,576 & -dividends & 3,458 \\
\hline Veterans' pensions & 2,448 & -other & 17,498 \\
\hline $\begin{array}{l}\text { Civil disability } \\
\text { pensions }\end{array}$ & 14,244 & & \\
\hline Blind pensions & 1,466 & SOCIAL INSURANCE CONTRIBUTIONS & 263,527 \\
\hline Deaf-mute pensions & 241 & & \\
\hline $\begin{array}{l}\text { Professional } \\
\text { orientation }\end{array}$ & 402 & IRAP & \\
\hline Housing & 205 & -public & 11,563 \\
\hline Other & 3,863 & -private & 40,081 \\
\hline Disease & 12,948 & & \\
\hline $\begin{array}{l}\text { PUBLIC } \\
\text { INSURANCE }\end{array}$ & & CONSUMPTION TAXES & 260,143 \\
\hline Maternity & 2,272 & -petroleum & 39,309 \\
\hline Family allowance & 8,030 & -vat & 220,834 \\
\hline Family & 6,934 & & \\
\hline Unemployment & 8,359 & & \\
\hline
\end{tabular}




\begin{tabular}{|l|l|l|l|}
\hline Accident & 7,601 & & \\
\hline & & $\begin{array}{l}\text { INDIVISIBILE GOVERNMENT } \\
\text { CONSUMPTION }\end{array}$ & 146,952 \\
\hline HEALTH CARE & & & \\
\hline - drugs & 12,833 & & \\
\hline - hospitals & 62,137 & & \\
\hline - doctor's \\
examinations & 28,265 & & \\
\hline - other & 13,213 & & \\
\hline EDUCATION & 75,559 & & \\
\hline
\end{tabular}


Table 2

\begin{tabular}{|l|c|c|c|c|c|c|c|c|c|}
\hline $\begin{array}{l}\text { WITHOUT IMMIGRANTS } \\
\text { millions lira }\end{array}$ & \multicolumn{3}{|c|}{$\begin{array}{c}\text { MIDDLE DEMOGRAPHIC } \\
\text { SCENARIO }\end{array}$} & \multicolumn{3}{c|}{$\begin{array}{c}\text { HIGH DEMOGRAPHIC } \\
\text { SCENARIO }\end{array}$} & \multicolumn{3}{c|}{$\begin{array}{l}\text { LOW DEMOGRAPHIC } \\
\text { SCENARIO }\end{array}$} \\
\hline Italians & male & female & average & male & female & average & male & female & average \\
\hline n.t.p.v. of the last living generation & 325,88 & 95,17 & 213,88 & 325,88 & 95,17 & 213,88 & 325,88 & 95,17 & 213,88 \\
\hline n.t.p.v. of the first future generation & 374,75 & 120,17 & 251,4 & 353,04 & 108,86 & 234,74 & 455,68 & 180,15 & 322,2 \\
\hline & & & & & & & & & \\
\hline generational imbalance & & & $15,24 \%$ & & & $7,60 \%$ & & & $40,69 \%$ \\
\hline tax growth & & & $5,20 \%$ & & & $2,33 \%$ & & & $24,75 \%$ \\
\hline WITH IMMIGRANTS & male & female & average & male & female & average & male & female & average \\
\hline n.t.p.v. of the last living generation & 325,88 & 95,17 & 213,88 & 325,88 & 95,17 & 213,88 & 325,88 & 95,17 & 213,88 \\
\hline n.t.p.v. of the first future generation & 374,75 & 109,59 & 238,38 & 339,28 & 96,52 & 221,44 & 435,08 & 165,34 & 304,12 \\
\hline & & & & & & & & & \\
\hline generational imbalance & & & $9,27 \%$ & & & $1,50 \%$ & & & $39,40 \%$ \\
\hline tax growth & & & $2 \%$ & & & $-1,90 \%$ & & & $20,17 \%$ \\
\hline
\end{tabular}

note:

n.t.p.v $=$ net taxes present value 
Table 3

\begin{tabular}{|l|c|c|c|c|}
\hline \multicolumn{2}{|l|}{ LOW DEMOGRAPHIC SCENARIO WITH IMMIGRANTS } \\
\hline immigrants'inflow & & 50.000 & 30.000 & 76.000 \\
\hline & & & & \\
\hline generational imbalance & $9,27 \%$ & $64,00 \%$ & $67,00 \%$ & $61,00 \%$ \\
\hline tax growth & $2,00 \%$ & $23 \%$ & $24,00 \%$ & $20,70 \%$ \\
\hline
\end{tabular}

note:

macroeconomic scenario with $\mathrm{r}=5 \%$ and $\mathrm{g}=2 \%$.

Table 4

\begin{tabular}{|c|c|c|c|c|}
\hline \multicolumn{5}{|c|}{$\begin{array}{l}\text { WITH IMMIGRANTS } \\
\text { millions lira }\end{array}$} \\
\hline \multirow{5}{*}{$\begin{array}{l}\text { high demographic } \\
\text { scenario } \\
\mathbf{r = 5 \%} \mathbf{g = \mathbf { 5 } \%}\end{array}$} & n.t.p.v. of the last living generation & 223,47 & 69,43 & 148,69 \\
\hline & n.t.p.v. of the first future generation & 260,65 & 91,04 & 178,31 \\
\hline & & & & \\
\hline & generational imbalance & $17,57 \%$ & & \\
\hline & tax growth & $8,47 \%$ & & \\
\hline \multirow{5}{*}{$\begin{array}{l}\text { middle demographic } \\
\text { scenario } \\
\mathbf{r = 4 \%} \mathbf{g}=\mathbf{2} \%\end{array}$} & n.t.p.v. of the last living generation & 325,88 & 95,17 & 213,88 \\
\hline & n.t.p.v. of the first future generation & 359,88 & 109,59 & 238,38 \\
\hline & & & & \\
\hline & generational imbalance & $9,27 \%$ & & \\
\hline & tax growth & $2,00 \%$ & & \\
\hline \multirow{5}{*}{$\begin{array}{l}\text { low demographic } \\
\text { scenario } \\
\mathbf{r = 3 \%} \mathbf{g = 2 \%}\end{array}$} & n.t.p.v. of the last living generation & 471,09 & 115,7 & 298,57 \\
\hline & n.t.p.v. of the first future generation & 670,89 & 243,46 & 463,39 \\
\hline & & & & \\
\hline & generational imbalance & $52,16 \%$ & & \\
\hline & tax growth & $25,76 \%$ & & \\
\hline
\end{tabular}

note:

n.t.p.v $=$ net taxes present value. 
Table 5

\begin{tabular}{|c|c|c|c|c|c|c|c|c|c|}
\hline \multirow[t]{2}{*}{ MIDDLE DEMOGRAPHIC SCENARIO } & \multicolumn{3}{|c|}{$\begin{array}{c}\text { FIRST MIGRATORY SCENARIO } \\
\text { (STABILIZATION) }\end{array}$} & \multicolumn{3}{|c|}{$\begin{array}{c}\text { SECOND MIGRATORY } \\
\text { SCENARIO (ONLY WORKING } \\
\text { AGE STAY) } \\
\end{array}$} & \multicolumn{3}{|c|}{$\begin{array}{c}\text { THIRD MIGRATORY } \\
\text { SCENARIO (ONLY FIVE YEARS } \\
\text { STAY) } \\
\end{array}$} \\
\hline & male & female & average & male & female & average & male & female & average \\
\hline$r=4 \% g=2 \%$ n.t.p.v. of the last living generation & 325,88 & 95,17 & 213,88 & 325,88 & 95,17 & 213,88 & 325,88 & 95,17 & 213,88 \\
\hline n.t.p.v. of the first future generation & 374,75 & 109,59 & 238,38 & 363,33 & 113,52 & 242,23 & 374,27 & 119,82 & 250,99 \\
\hline generational imbalance & & & $9,27 \%$ & & & $11,30 \%$ & & & $15,00 \%$ \\
\hline tax growth & & & $2 \%$ & & & $2,73 \%$ & & & $5,18 \%$ \\
\hline
\end{tabular}

note: $\quad$ n.t.p.v $=$ net taxes present value.

macroeconomic scenario with $\mathrm{r}=4 \%$ and $\mathrm{g}=2 \%$. 


\title{
Our papers can be downloaded at:
}

\author{
http://cerp.unito.it
}

CeRP Working Paper Series:

\begin{tabular}{|c|c|c|}
\hline $\mathrm{N}^{\circ} 1 / 00$ & Guido Menzio & Opting Out of Social Security over the Life Cycle \\
\hline $\mathrm{N}^{\circ} 2 / 00$ & $\begin{array}{l}\text { Pier Marco Ferraresi } \\
\text { Elsa Fornero }\end{array}$ & $\begin{array}{l}\text { Social Security Transition in Italy: Costs, Distorsions } \\
\text { and (some) Possible Correction }\end{array}$ \\
\hline $\mathrm{N}^{\circ} 3 / 00$ & $\begin{array}{l}\text { Emanuele Baldacci } \\
\text { Luca Inglese }\end{array}$ & $\begin{array}{l}\text { Le caratteristiche socio economiche dei pensionati in } \\
\text { Italia. Analisi della distribuzione dei redditi da pensione } \\
\text { (only available in the Italian version) }\end{array}$ \\
\hline $\mathrm{N}^{\circ} 4 / 01$ & Peter Diamond & Towards an Optimal Social Security Design \\
\hline$N^{\circ} 5 / 01$ & Vincenzo Andrietti & $\begin{array}{l}\text { Occupational Pensions and Interfirm Job Mobility in the } \\
\text { European Union. Evidence from the ECHP Survey }\end{array}$ \\
\hline
\end{tabular}

N ${ }^{\circ}$ 6/01 Flavia Coda Moscarola The Effects of Immigration Inflows on the Sustainability of the Italian Welfare State 
